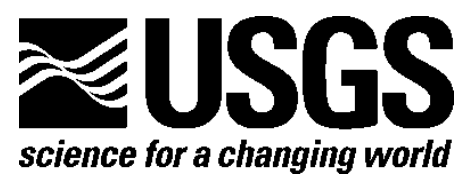

Prepared in cooperation with the Polish Geological Institute

\title{
Evaluation of Landslide Monitoring in the Polish Carpathians
}

Brian D. Collins, Rex L. Baum, Teresa Mrozek, Piotr Nescieruk, Zbigniew Perski, Wojciech Rączkowski, and Marek Graniczny

Open File Report 2011-1001

U.S. Department of the Interior U.S. Geological Survey 


\title{
U.S. Department of the Interior \\ KEN SALAZAR, Secretary
}

\author{
U.S. Geological Survey \\ Marcia K. McNutt, Director
}

U.S. Geological Survey, Reston, Virginia 2011

For more information on the USGS - the Federal source for science about the Earth, its natural and living resources, natural hazards, and the environment:

World Wide Web: http://www.usgs.gov

Telephone: 1-888-ASK-USGS

\author{
Suggested citation: \\ Collins, B.D., Baum, R.L., Mrozek, Teresa, Nescieruk, Piotr, Perski, Zbigniew, \\ Rączkowskj Wojciech, and Graniczny, Marek, 2011, Evaluation of landslide \\ monitoring in the Polish Carpathians: U.S. Geological Survey Open-File Report, \\ 2011-1001, 30 p. [http://pubs.usgs.gov/of/2011/1001/].
}

Any use of trade, product, or firm names is for descriptive purposes only and does not imply endorsement by the U.S. Government.

Although this report is in the public domain, permission must be secured from the individual copyright owners to reproduce any copyrighted material contained within this report. 


\section{Contents}

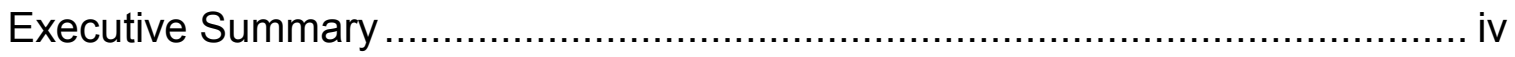

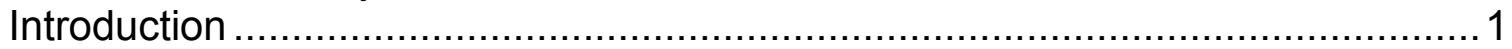

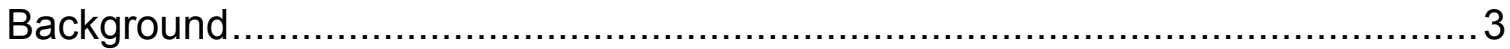

Regional Setting and General Overview of Landsliding in the Polish

Carpathians .................................................................................... 3

Climate and Storm Events of Spring and Summer 2010 in Southern Poland ....4

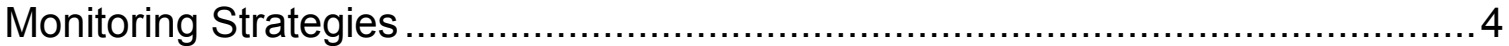

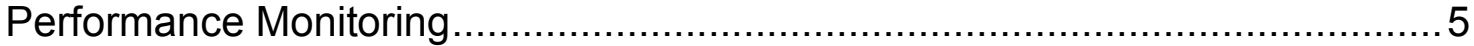

Real-Time Warning System Monitoring ...................................................... 5

Near-Real-Time Monitoring for Early Warning ............................................... 6

Research Monitoring........................................................................

Evaluation of Existing PGI Monitoring Locations and Recently Reactivated

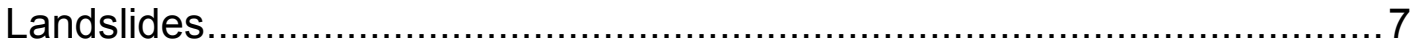

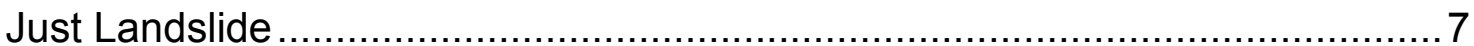

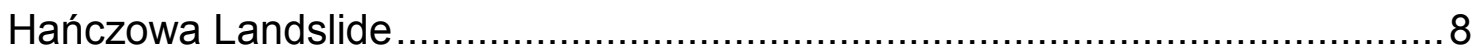

Szymbark (Huciska and Zapadle) Landslides ........................................... 10

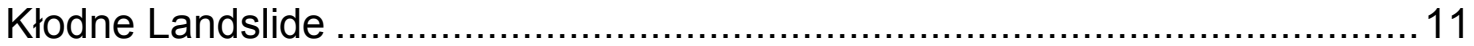

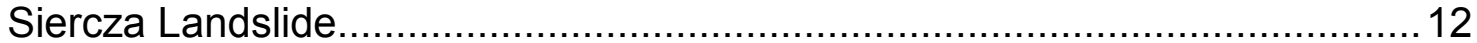

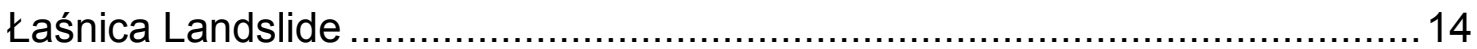

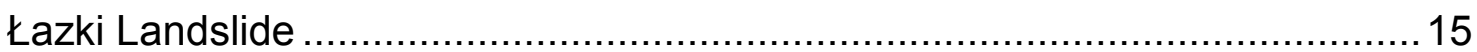

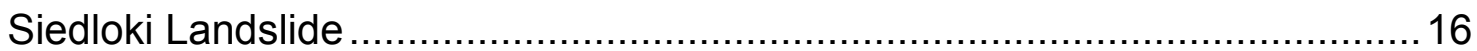

Example of a Near-Real-Time Warning System ........................................ 19

Managing Public Perceptions about Real-Time Landslide Monitoring and Early

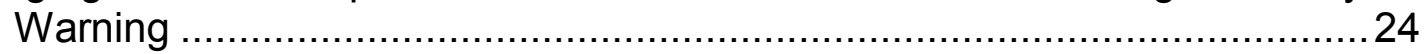

Potential Research Questions To Be Answered By Monitoring .......................25

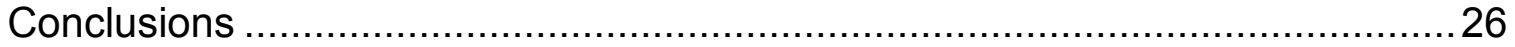

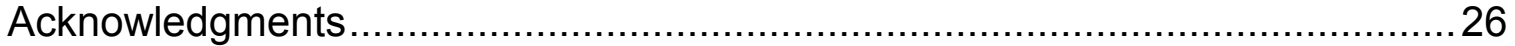

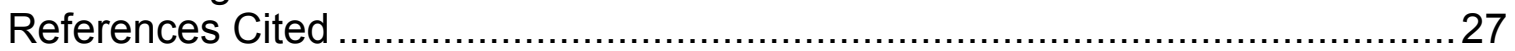

\section{Figures}

Figure 1. Location map of Poland showing landslide sites visited in September 2010.

Figure 2. Sketch map, cross section, and details, of hypothetical landslide .......20

\section{Tables}

Table 1. Summary monitoring suggestions for landslide sites visited in Poland,

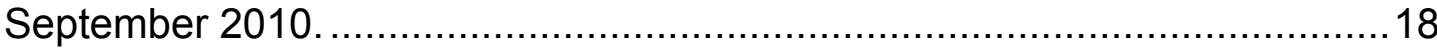

Table 2. Equipment for near-real-time monitoring of hypothetical landslide. ......22

\section{Appendix}

Appendix A. General Considerations for Real-Time and Near-Real-Time Monitoring 


\section{Executive Summary}

In response to the June 15, 2010 request from the Polish Geological Institute (PGI) to the U.S. Geological Survey (USGS) for assistance and advice regarding realtime landslide monitoring, landslide specialists from the USGS Landslide Hazard Program visited PGI headquarters and field sites in September 2010. During our visit we became familiar with characteristics of landslides in the Polish Carpathians, reviewed PGI monitoring techniques, and assessed needs for monitoring at recently activated landslides.

Visits to several landslides that are monitored by PGI (the Just, Hańczowa, Szymbark, Siercza and Łasńica landslides) revealed that current data collection (monthly GPS and inclinometer surveys, hourly piezometers readings) is generally sufficient for collecting basic information about landslide displacement, depth, and groundwater conditions. Large landslides are typically hydrologically complex, and we would expect such complexity in Carpathian landslides, given the alternating shale and sandstone stratigraphy and complex geologic structures of the flysch bedrock. Consequently groundwater observations could be improved by installing several piezometers that sample the basal shear zone of each landslide being monitored by PGI. These could be supplemented by additional piezometers at shallower depths to help clarify general flow directions and hydraulic gradients. Remedial works at Hańczowa make the landslide unsuitable for monitoring as part of an early warning network. Monitoring there should focus on continued performance of the remedial works.

Our suggestions for new monitoring at recently activated landslides are summarized in table 1. Displacement monitoring using extensometers and (or) GPS is a high priority at Kłodne, Łaśnica, Łazki, and Siedloki. Geomorphologic mapping of active surface features (scarps, cracks, shear zones, folds, and thrusts) in sufficient detail to reveal the kinematics of each landslide would greatly help in planning subsurface exploration and monitoring. Mapping should take advantage of existing and future airborne lidar data sets of specific areas, where available. Borehole inclinometers and piezometers would complete the basic monitoring package for these landslides. The landslide at Kłodne may be well suited for more detailed monitoring for landslide process research, although research opportunities exist at the other landslides as well. The landslide near Siedloki may be a good candidate for terrestrial laser scanning (TLS). Tandem streamflow gages upstream and downstream from the Siedloki landslide, or laser distance meters to monitor advancement of the toe, may be needed to provide warning of stream blockage of Potok Milowski. A real-time warning system specifically for the Łazki landslide might be considered due to potential concerns about catastrophic movement into Międzybrodzie Reservoir.

Challenges associated with the establishment of a complete real-time monitoring and early warning system are far greater than just the technical and logistical aspects of installing remote monitoring systems at a large number of landslides. Long-term maintenance of a landslide monitoring network will involve considerable effort and expense as sensors break-down from exposure to weather, landslide movement, and harsh underground environmental conditions.

Once PGI's planned pilot network of 10-20 monitored landslides is operating, a period of observation and analysis will be needed to establish appropriate alert levels and 
criteria for issuing alerts and warnings. Simultaneously, discussions with authorities will be needed to develop action plans for responding to landslide notifications and (or) warnings. Public resistance to landslide warnings and mandated evacuations may be high given the low historical incidence of fatalities and injuries resulting from Carpathian landslides and the small potential for warnings to reduce landslide damage to homes and land. Careful weighing of purpose, advantages, and costs of a large-scale monitoring and early warning program is needed early in the planning process and should be revisited regularly throughout pilot and final implementation.

In this report, we present a generic plan for monitoring of a hypothetical Carpathian landslide that illustrates how our suggestions for each of the specific landslides could be implemented. The plan includes basic pore pressure, displacement, and weather monitoring, along with supplemental monitoring for special conditions at specific landslides. Table 2 summarizes the overall approach and basic equipment and software requirements. 


\title{
Evaluation of Landslide Monitoring in the Polish Carpathians
}

\author{
Brian D. Collins ${ }^{1}$, Rex L. Baum ${ }^{2}$, Teresa Mrozek ${ }^{3}$, Piotr Nescieruk ${ }^{3}$, Zbigniew \\ Perski $^{3}$, Wojciech Rączkowski ${ }^{3}$, and Marek Graniczny ${ }^{4}$ \\ ${ }^{1}$ U.S. Geological Survey, Geology and Geophysics Science Center, Menlo Park, California, USA \\ ${ }^{2}$ U.S. Geological Survey, Geological Hazards Science Center, Golden, Colorado, USA \\ ${ }^{3}$ Polish Geological Institute, Carpathian Branch, Kraków, Poland \\ ${ }^{4}$ Polish Geological Institute-National Research Institute, Warsaw, Poland
}

\section{Introduction}

During late spring 2010, in the course of discussions about potential collaboration between the Polish Geological Institute (PGI) and the U.S. Geological Survey (USGS), widespread activation of hundreds of landslides occurred in the Carpathian Mountains of southern Poland. This resulted in an urgent request, dated June 15, 2010, from PGI for USGS assistance regarding real-time landslide monitoring and early warning systems. The request called for advice on automated data-acquisition equipment, instrumentation, and software for real-time monitoring of individual landslides and for a visit by USGS landslide experts to review methods of monitoring currently used by PGI. In response to this request, copies of two USGS reports on landslide-monitoring techniques were sent immediately (Baum and others, 2008; Reid and others, 2008), and in September 2010 a team of two USGS landslide specialists, Rex Baum and Brian Collins, were sent to meet with PGI officials. The USGS specialists visited examples of monitored and recently activated landslides for the purpose of developing suggestions about monitoring and discussing potential cooperation between the two agencies.

Meetings between USGS researchers (Baum and Collins) and PGI officials (Chief Director Jerzy Nawrocki, Wojciech Brochwicz-Lewiński, Dariusz Grabowski, Marcin Kułak, and Teresa Mrozek) took place at PGI headquarters in Warsaw, Poland on September 9, 2010. Field visits with PGI geologists (Teresa Mrozek, Piotr Nescieruk, Wojciech Rączkowski and Zbigniew Perski) took place over four days between September 10-14, 2010. At the meeting in Warsaw, PGI briefed the USGS about ongoing development of a detailed landslide database and hazard-zone maps (based on expert opinion), as well as plans for monitoring of up to 100 landslides. The pilot phase of landslide monitoring is expected to involve between 10 and 20 landslides. USGS understood from the briefing that PGI places high priority on selecting methods for (1) objective, probabilistic landslide-hazard zonation and (2) real-time landslide monitoring to address a directive from the Polish Ministry of Environment to provide information about when landslide acceleration or reactivation can be expected. USGS researchers briefed PGI officials about landslide-monitoring techniques and landslide-hazard 


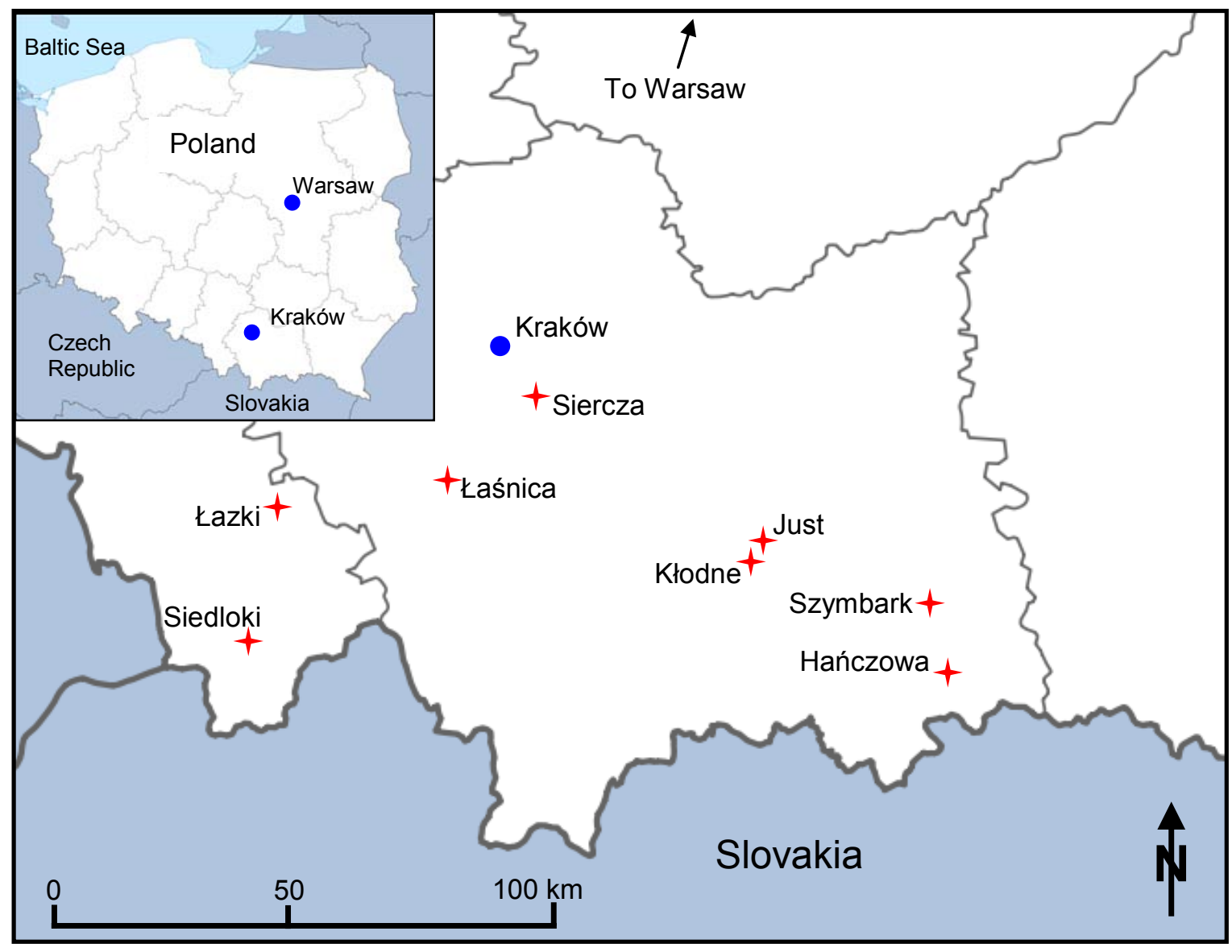

Figure 1. Location map of Poland showing landslide sites visited in September 2010.

zonation methodologies developed by the USGS. During field investigations we visited eight landslides in detail (fig. 1) and stopped briefly at several others.

The remainder of this report provides brief descriptions of the landslides that we visited, our assessments of current monitoring at each site, and suggestions for further development of existing monitoring systems or development of new monitoring systems at recently activated landslides. Additional comments are provided about definitions and descriptions of four general classes or types of monitoring, a detailed description of a monitoring system for a hypothetical landslide in the Carpathian Mountains, some comments about the sociological aspects of real-time landslide monitoring and early warning, and a list of lessons learned from USGS monitoring experiences. 


\section{Background}

\section{Regional Setting and General Overview of Landsliding in the Polish Carpathians}

Landsliding in Poland is predominantly confined to the southern portion of the country in the area of the Polish Flysch Carpathian Mountains. More than 90 percent of all landslides occur within this area, which represents only 6 percent of the land area of Poland (Wójcik and others, 2006). About 60,000 known landslides have been mapped and included in PGI's database (Marcin Kułak, personal commun., 2010). The area is part of the larger Carpathian thrust and fold range that stretches in an arc from Austria (the Vienna Basin) in the west, through Slovakia, the Czech Republic, Poland, and Ukraine in the north, to Romania (the Iron Gate) and Serbia in the southeast. The Carpathians are subdivided into the Western and Eastern Carpathians (the latter also called the Southeastern Carpathians) depending, in general, on their respective physiography. These are further divided into specific ranges, basins, and plateaus (for example, Beskid Niski and Pogórze Wielickie in Poland). Subdivisions along the arcuate mountain range of the Outer Carpathians and Inner Carpathians are attributed mainly to structural, tectonic, and lithologic differences.

The Polish Outer Carpathians are dominated by Cretaceous to Tertiary (Paleogene) flysch deposits consisting of sequential layers of shales and sandstones deposited in a deep marine basin during continental mountain building. Younger (late Tertiary) sediments sometimes overlie the flysch deposits. The flysch deposits of specific sedimentary basins form rock series (successions) where the nappes are thrust over one another and also over the Carpathian foredeep. The successions are named after the nappes (for example, Magura, Silesian, Sub-Silesian, and Skole Nappes) and reflect specific sedimentary conditions of particular basins. In Poland, to simplify a rather complicated sedimentary pattern, the flysch deposits are occasionally divided into three major categories: (1) normal flysch, consisting of adjacent sandstone and shale beds of approximately equal thickness, (2) shale flysch, where shale beds are thicker than adjacent sandstone beds, and (3) sandstone flysch, where the opposite holds. Thrusting and consequent folding of the greater Carpathians has fractured and folded the majority of flysch deposits throughout most of southern Poland. Whereas landsliding along (parallel to) shale beds is common, landslides occur in all flysch deposit types and both parallel and perpendicular to existing geologic structures. In addition, landsliding in younger Miocene clays is also common (Wójcik and others, 2006).

Historical landsliding in Poland is well documented and investigated. Studies show that some landslides can be traced back to environmental changes associated with Pleistocene post-glacial warming and Holocene climate swings (Alexandrowicz and Alexandrowicz, 1999) and that reactivation of older Holocene landslides has occurred in more recent times (Bajgier-Kowalska, 2008). Studies on recent landslides show definitive quantitative signals between precipitation, groundwater level and landsliding in several areas (Gil and Długosz, 2006; Gil and others, 2009; Zabuski and others, 2009). Finally, recent geotechnical studies show that high pore-water pressures are often the trigger for deep-seated landslides (Bednarczyk, 2008), suggesting that basal pore water pressure measurements might be the best indicators of future landslide movements. 


\section{Climate and Storm Events of Spring and Summer 2010 in Southern Poland}

Southern Poland has a temperate climate influenced by both Atlantic maritime and Eastern European continental conditions. Summer brings warm (average temperature $21^{\circ} \mathrm{C}$ ), comfortable temperatures, whereas winter brings cold (average temperature $0^{\circ} \mathrm{C}$ ) and snow. In general, rainfall is highest in the summer months (June, July, August), but can be severe in spring as well. The city of Kraków, located in the central area of southern Poland receives approximately $631 \mathrm{~mm}$ of rainfall annually (Institute of Meteorology and Water Management, 2010). When coupled with snowmelt events, early spring rainfall can cause flooding, although rainfall alone has also caused extensive and more frequent flooding in the past.

Southern Poland received heavy snowstorms during the winter of 2009-2010, and consequent melting in the spring led to high groundwater conditions and saturated soils. In May 2010 a low pressure system developed over Genoa Bay (northern Mediterranean Sea). This was followed by another low pressure system affecting Poland that followed a more typical meridional track moving from the Balkan Peninsula to Central Europe and subsequently, became stationary there. The warm, moist air masses from the low pressure systems gliding over colder air from the northwest and orographically lifted by the Carpathian Mountains brought about prolonged and intense precipitation, and finally flooding, in southern Poland. Daily precipitation exceeded typical monthly levels from May 15-17, with reports of $200 \mathrm{~mm}$ of rain in 24 hours (Telegraph, 2010). Flooding led to several fatalities and levee breaches in central and southern Poland. Landslides resulting from high levels of precipitation were distributed across a wide area throughout southern Poland. Additional storms in early June (June 1-3) resulted in more than 100 mm of rainfall (World Meteorological Organization, 2010). This led to continued flooding and reactivation and mobilization of both existing and new landslides. Storms in August and again in September resulted in additional flooding and reactivation of existing landslides and activation of new landslides.

No fatalities due to landsliding were reported from these events, in large part because landslide velocities were generally slow (meters per day). As a result, residents evacuated either on their own, or were assisted by local authorities and building inspectors. Cracking of plaster and brick homes was ubiquitous where structures were located within landslide boundaries. Structures typically collapsed completely where deformation was severe, usually after meters of displacement. Due to the severe levels of damage suffered in many communities, Polish and European Union emergency funds became available for repair and reconstruction efforts. During our site visit, we were informed that some displaced residents of damaging landslides had already begun to relocate in areas away from their damaged homes.

\section{Monitoring Strategies}

Landslide monitoring can take various forms which are typically selected with specific purposes in mind. For example, in some cases, monitoring may be desired to confirm the performance of already built mitigation structures. In other cases, monitoring may be required as part of an early warning system. We have defined four categories of monitoring to aid in describing and organizing our suggested landslide-monitoring 
approaches and equipment at each of the sites investigated: (1) performance monitoring, (2) real-time monitoring for warning, (3) near-real-time monitoring for warning, and (4) research monitoring. These categories, described below, have been developed based on our general discussions with PGI officials in Warsaw, our site-specific evaluations with PGI geologists in the field, and our own understanding of and experience with landslidemonitoring systems and their purposes.

\section{Performance Monitoring}

When mitigation measures have been implemented to either arrest landslide movement or protect existing infrastructure, performance monitoring may be desired as a means to determine if mitigation structures are acting effectively. In these cases, monitoring will typically consist of some form of displacement instrumentation (for example, downhole inclinometers, surface tiltmeters, or geodetic-survey measurements). The purpose of this type of instrumentation is to confirm that deformations are not taking place with respect to the mitigation or protected structure. In many cases there may not be a need for real-time or near-real-time monitoring because of an assumption that the mitigation strategy will act according to design. Thus, monthly or annual measurements are typical and may be sufficient. If a high-sampling rate is desired (that is, less than once per month), a stand-alone datalogger and batteries/power connection are suggested with sufficient capacity to make and store measurements between manual download intervals by personnel sent to the field. However, remote-access capability (for example, cell phone uplink) may also be integrated. For sampling rates greater than once per month, it may be sufficient to send personnel directly to the field to make each measurement, depending on travel distance. Regularly scheduled maintenance of instrumentation and dataloggers should be implemented, but in general, is not as critical compared with other monitoring strategies.

\section{Real-Time Warning System Monitoring}

In cases where lives or infrastructure are threatened directly by landslide motion, a real-time monitoring system may be desired. These systems typically use displacementmeasurement instrumentation (for example, inclinometers, tiltmeters, and extensometers), but may also consist of surface and subsurface hydrologic-response instrumentation (for example, piezometers and streamflow gages), as well as weather instrumentation (precipitation, air temperature, barometric pressure). This instrumentation is typically used to detect landslide deformation or acceleration, but may also be used to detect if hydrologic or meteorologic conditions are sufficient to trigger landslide motion. An example of this latter purpose would be measuring landslide basal shear zone pore-water pressures in conjunction with an existing deterministic slope stability model to evaluate landslide stability (that is, Are pore water pressures sufficient to cause a factor of safety less than 1.0?). In this example, a thorough knowledge of the landslide topography, geometry, geology, and style of motion are necessary. Typically, instrumentation sampling rates are on the order of seconds during peak triggering conditions (for example, during heavy precipitation). Systems must, therefore, be capable of detecting a rapid event. These systems require installation of one or more dataloggers, radio/cell phone/satellite/IP modem uplink capability, and a continuous, dependable power supply. Redundant systems of dataloggers, sensors, communications, and power are generally 
needed for remote monitoring of potentially hazardous landslides. Additionally, a schedule of periodic maintenance should be implemented and strictly followed to ensure the functionality of all monitoring-system components. If a component of the system fails, repair should be made within 24 hours, if possible and safe to do so. A decision matrix should be implemented prior to bringing the system online based on a clear understanding of the data and its meaning with regard to slope stability. The decision matrix should include a carefully defined list of actions to take at each predefined level of hazard. Finally, prior arrangements must be made with local authorities to react rapidly (within seconds to at most minutes) and appropriately should the instrumentation indicate a hazardous condition.

\section{Near-Real-Time Monitoring for Early Warning}

A near-real-time warning system is typically desired when incoming data is important for understanding current field conditions, but when acting upon these conditions immediately is not required. "Early warning", as used here, indicates data collection, transmission, and interpretation capabilities on the order of 10 minutes to several hours. As an example, this type of application could be implemented when municipal officials would like to know when conditions for landsliding are likely to occur so that they can be in a position to either inform or warn residents, or to prepare emergency-response equipment and personnel (for example, electrical utility crews). Here, knowing the exact moment of landsliding is not necessarily required, but being prepared for an adverse circumstance is desired, particularly if potential changes in field conditions occur slowly (that is, over tens of minutes to hours). Near-real-time warning systems can utilize a wide range of instrumentation types, including those for surfaceand subsurface-displacement monitoring, surface- and subsurface-hydrologic monitoring, and weather monitoring. Instrumentation sampling rates are typically between 10 minutes and several hours in length. Similar to real-time warning system monitoring, a full suite of dataloggers, uplink systems, and dependable power supplies are needed, but redundancy of components is less critical. In general, instrumentation does not need to be maintained as frequently as for real-time systems. With near-real-time systems, if there is a problem with any part of the instrumentation installation, it is generally acceptable to be able to fix the problem within a 14-day period outside the storm season and within a 48 to 72-hour period during storm season (depending on the proximity of other monitoring stations and how rapidly landslides respond to rainfall). Still, regular (semiannual or annual) maintenance should be performed to ensure functionality prior to storm seasons. Certain types of instruments, such as tensiometers, may require maintenance on a more frequent (quarterly or monthly) basis. Depending on the application, a decision matrix for interpreting the various data signals may be necessary. If the goal of the system is to warn municipalities that landslide conditions exist, the definition of various condition types (for example, “Outlook", "Watch”, or "Warning”; see Chleborad and others, 2008) must be clearly delineated and a means to convey this information must be implemented and maintained (for example, contact information for various end users should be regularly checked and updated). As in the case of a real-time warning system, clear instructions need to be developed concerning actions to be taken by end-users and the general public. 


\section{Research Monitoring}

In some cases, monitoring may be desired for the purpose of understanding the underlying phenomena that is causing landsliding (Reid and others, 2008). This type of monitoring, termed "research monitoring" is usually aimed at collecting data to assist in answering a particular scientific question. Although in most cases, data provided by a real-time or near-real-time system will be perfectly sufficient for answering research questions, there are situations where warning systems are not necessary, and the data can be logged without the need for continuous uplink and transmission from a remote location. For example, if the kinematics of a particular landslide may assist in explaining a general stability or hydrologic concept common to other landslide areas, a single landslide may be rigorously instrumented to learn about this behavior. In these cases, there may be no imminent danger or societal affect from the landslide, and thus, remote data transmission may not be necessary. Rather, all data may be able to be logged on site and periodically retrieved. A downside of this type of configuration however, is that if instrumentation fails, the cause and timing will not be known until the time of the next site visit. Further, any cost savings realized by eliminating a communications link may be partially offset by increased travel costs and field time needed to collect data. Maintenance schedule and repair requirements for research monitoring systems are similar to those for near-real-time monitoring systems.

\section{Evaluation of Existing PGI Monitoring Locations and Recently Reactivated Landslides}

The following site descriptions and suggestions have been prepared based on our understanding of each landslide obtained through site visits, discussions with PGI geologists, and a review of documents provided by PGI. In the section title for each landslide, a suggested level of monitoring (monitoring strategy), as described previously, is included. Each site description contains three sections outlining (1) the location, setting, and description of recent damage; (2) a general description of landslide dimensions and monitoring methods currently used; and (3) an evaluation of existing monitoring and suggestions for additional monitoring that could be implemented. A summary is provided in table 1 , following the site-specific discussions. Note that our suggestions are not based on financial, logistical, or societal implications for each location.

\section{Just Landslide}

The Just landslide is located north of the city of Nowy Sacz on the west side of Rożnów Reservoir in the Beskid Wyspowy region of the Outer Western Carpathian Mountains. The landslide reactivated in June 2010 following heavy rainfall in May and a storm on June 2; it has caused ongoing deformations to a main road (National Route 75) through the area, and continual road repair has been required. In addition, several houses located on the landslide have been damaged. The landslide toe is exposed the edge of Rożnów Reservoir, and some researchers have speculated that reservoir lowering and filling may control movement of the landslide.

The landslide is approximately $300 \mathrm{~m}$ wide by $550 \mathrm{~m}$ long, with a basal shearzone depth of about $18 \mathrm{~m}$ (as measured near the toe). The landslide is developed in 
sandstone and shales of the Magura rock series unit (shale flysch deposit). Two existing inclinometer/piezometer "nests" (places where multiple sensors are installed) are located on the northeast half of the landslide, one in the upper third of the landslide and one near the toe. In addition, a network of eight GPS survey points is distributed on the landslide surface. Piezometers are recorded hourly and manually downloaded periodically, whereas inclinometers are monitored monthly. GPS survey points are monitored using geodeticgrade differential-GPS equipment twice per year and following snowmelt and large precipitation events.

Our review of the Just landslide was not as thorough as for other sites and therefore the following suggestions are based on a limited understanding of this site. Based on our field visit with PGI personnel, we think that this site is a probable candidate for a near-real-time monitoring system. Monitoring protocols should be developed based on (1) identifying when deformation of the road is increasing, decreasing, or stable and (2) identifying the role of piezometric and reservoir levels on landslide response. Monitoring deformation to the road will most likely be possible by using the inclinometer already located within the upper portion of the landslide (PGI designation JP-1) or by using new, ultra-short baseline $(<1 \mathrm{~km})$ differential-GPS monitoring. This latter option would take considerable resources in terms of GPS receivers, dataloggers, and datauplink devices, but would provide a means to monitor near-road deformation directly. Highly sensitive $\left(10^{-4}\right.$ unit strain) soil strain-meters are another possible option. These devices might detect deformation earlier than GPS monitoring. Strain measurement at selected locations near Highway 75 might be a useful supplement to the displacement monitoring. Detailed geomorphologic mapping of the internal structures (for example, scarps, shear zones, folds) formed during the recent activation of the landslide would be needed to define its kinematic elements and guide instrument placement for displacement and strain monitoring. Monitoring of piezometric levels should focus on the basal shear zone to provide a direct measure of pore-water pressure that controls landslide movement. If the location of the basal shear zone is known, sensors should be placed just above this zone to avoid being sheared or damaged. Sensors could be installed using the existing piezometers with additional borehole development and by addition of a datalogger and either satellite, cell phone, or IP modem uplink. We also suggest at least two more piezometer nests in the main body of the landslide because our experience indicates that multiple piezometers are typically needed to adequately determine relevant pore pressures at the basal shear zone or to resolve questions about landslide hydrology (Baum and Reid, 1995; Reid and others 2008). We also suggest synchronous hourly (or more frequent) measurements of reservoir level, pore pressure at the toe of the landslide, and landslide displacement near the toe to test for direct correlation between reservoir level and landslide motion. A pressure-head transducer or water-level sensor located in the reservoir below its low water level would be needed in addition to the piezometers and GPS units discussed previously.

\section{Hańczowa Landslide}

The Hańczowa landslide is located just north of the village of Hańczowa, on the west bank of the Ropa River in the Beskid Niski region at the eastern tip of the Polish Outer Western Carpathian Mountains. The landslide has caused periodic deformation and closure of an important roadway that accesses resort areas in Wysowa-Zdrój near the 
Polish-Slovakian border. No habitable structures are located within the landslide boundaries. Due to ongoing concerns with keeping the road open, mitigation measures were installed that include horizontal drains, a toe buttress, a $40 \mathrm{~m}$ realignment of the Ropa River away from the landslide toe, and river bank erosion protection where the river cuts the toe. During our site visit, the mitigation appeared to be functioning adequately, although we did not check any drains for integrity, nor view any instrumentation data.

The current landslide dimensions are about 280 m wide, $210 \mathrm{~m}$ long, and 16-21 m deep. The toe of the basal shear zone is exposed in the middle of the Ropa River curving upwards at a 23 degree angle relative to horizontal, indicating local rotational motion. Overall the landslide slopes approximately 8 degrees, and movement appears to be mainly translational. Our on-site observations indicate the basal shear zone at the toe is composed of plastic, variegated clays with seemingly low shear strength. The landslide itself is located within the Magura rock-series unit, represented by beds of Magura sandstone and variegated shales (shale flysch deposit). Surficial expression of the landslide is fairly subtle due to mature vegetation in the area, however several scarps with up to several meters of downward displacement can be discerned amidst the trees. Existing instrumentation consists of three inclinometer/piezometer nests, a tipping-bucket rain gage on the east bank of the river, and 12 GPS survey points. Piezometers are openhole type with the sensor located at the bottom of each borehole, coincident with maximum inclinometer depth. Piezometers are recorded hourly and downloaded periodically, whereas inclinometers are monitored monthly. GPS survey points are monitored using geodetic-grade differential-GPS equipment twice per year and following snowmelt and large precipitation events.

Based on our site visit and discussions with PGI geologists, we find that this site is a likely candidate for performance monitoring. The landslide has already been extensively mitigated, and monitoring should focus on whether or not the mitigation scheme is functioning to prevent additional deformation to the road. In our opinion, the mitigation works probably make this landslide unsuitable for inclusion in an early warning network. We find the existing displacement-monitoring instrumentation, locations, and schedule adequate for performance monitoring, although we do suggest that the piezometers be transitioned to be screened directly above the basal shear zone. If desired, it is possible that at least some data could be transmitted remotely to provide a near-real-time assessment of site conditions. This could include some form of displacement- and additional piezometric-response monitoring. We understand that there may be some concerns with vandalism of instrumentation in this area and thus we do not suggest using permanent GPS stations to monitor displacement. Rather, some form of automated downhole inclinometer measurement would provide a more protected, but still meaningful signal. The depth of measurement should be determined based on the basal shear-zone depth. Likewise, existing piezometers should also be screened and isolated over the basal shear-zone location to provide a more meaningful record of pore water pressures that might be affecting landslide motion. Finally, we suggest that some form of displacement monitoring also be implemented at the toe. This could be in near-real-time mode, using a permanent pulsed laser signal. One or more laser distance meters, controlled by a datalogger, could be positioned on the east bank of the river and aimed at a target or targets on the west bank. Alternatively, toe deformation could be monitored on 
a repeat field-visit schedule by using terrestrial lidar to capture the topography of the entire landslide toe. Performing high-resolution change detection on repeat lidar surveys could also provide a more complete assessment concerning any future deformation in this area. Based on our experience, dense vegetation above the road makes the upper landslide region unsuitable for terrestrial lidar monitoring. This type of vegetation would prevent the collection of sufficient data needed to construct a useable topographic surface model for change-detection monitoring.

\section{Szymbark (Huciska and Zapadle) Landslides}

The Szymbark-area landslides are located southeast of the town of Szymbark in the Beskid Niski region at the eastern tip of the Outer Western Carpathian Mountains. The landslides, one each on opposite sides of the Bielanka River, are coincident with two nearby villages (Huciska and Zapadle). The landslides initially reactivated as a result of heavy rainfall in 1997 and have been periodically active since 1997. The Bielanka River is thought to control continued movement at these landslides. River effects may include direct unloading of the toe through bed erosion, increased pore water pressure on the basal shear zone at the toe, or a combination of these effects. In addition to periodically blocking the river and damaging the road that runs along the toe of both landslides, these landslides have destroyed and damaged several houses in recent years. Average landslide-surface velocities are on the order of $0.08 \mathrm{~m} / \mathrm{yr}$ (approximately $0.4 \mathrm{~m}$ in 5 years) on the Huciska landslide, with higher rates of $0.5 \mathrm{~m} / \mathrm{yr}$ (approximately $2.5 \mathrm{~m}$ in 5 years) on the Zapadle landslide.

The Huciska landslide is about $400 \mathrm{~m}$ wide and $750 \mathrm{~m}$ long with a basal shear zone at approximately $12 \mathrm{~m}$ depth. The Zapadle landslide is about $750 \mathrm{~m}$ wide at the river and $975 \mathrm{~m}$ long with a basal shear zone at approximately $18 \mathrm{~m}$ depth. Basal shear zones of both landslides are below river bed elevation. Average surface gradients over the length of each landslide are about 7 degrees, and both landslides are located in variegated shale-dominated flysch deposits. Because of the importance of the road to area residents, PGI installed monitoring equipment on both landslides, beginning with GPS monuments approximately 5 years ago and inclinometer-piezometer nests in 2009. A decision on future mitigation options to protect the road and existing houses will depend on the results of additional landslide investigations. Existing instrumentation at Huciska consists of three inclinometer-piezometer nests and seven repeat-GPS survey points. Existing monitoring at Zapadle consists of two inclinometer-piezometer nests and eight GPS survey points. Our review of PGI documents also indicates that several additional GPS survey points exist off the existing landslide boundaries. Piezometers are recorded hourly and periodically downloaded manually, whereas inclinometers are monitored manually each month. GPS survey points are monitored twice per year and following snowmelt and large precipitation events.

Based on our field visit with PGI personnel and review of site-related documents, we find that the existing monitoring locations with regard to inclinometers and piezometers is sufficient for capturing future potential road deformation from both landslides. River-induced toe erosion is a likely trigger for additional slope movement and the existing inclinometers are located effectively near the toe to detect deformation in this area. We also find that the monitoring schedule is appropriate (hourly piezometer readings and monthly inclinometer readings) for capturing potential hydrologic and 
mobilization response. With regard to potential near-real-time monitoring, we find that some additional monitoring is possible. Piezometers could be connected to dataloggers and up-linked directly to provide a continuous data stream of measurements. Given the surficial displacement already measured at the Zapadle landslide (2.5 $\mathrm{m}$ in 5 years), it is likely that existing inclinometers may not be able to measure long-term movement of the landslide before casings are sheared. Therefore, we do not suggest permanent down-hole inclinometers for this landslide. Rather, we suggest either installing cable-type extensometers in the boreholes, before the casings are sheared, or continuing surficial monitoring of the landslide by using the existing GPS survey points. If extensometers are selected, these measurements could be connected to a datalogger for direct uplink. If GPS monitoring in near-real-time mode is selected, significant upgrades and equipment investment will be necessary, including installation of a dedicated, ultra-short-baseline $(<1 \mathrm{~km})$, differential-GPS base-station receiver and dedicated GPS receivers on each survey point of interest. We also find that surficial tiltmeter monitoring may be ineffective for this landslide due to its shallow surface gradient. One additional inclinometer and piezometer nest in the upper parts of both landslides could be installed to assist in constraining subsurface basal shear zone motion in those locations. An additional GPS survey point in the upper part of the Zapadle landslide complex could also be helpful for capturing potential motion directly downslope from the head scarp. Piezometers could potentially be installed at different depths coincident with identified basal shear-zone depths from inclinometer measurements, such that the pore pressure response on the basal shear-zone is quantified. Finally, we suggest that a new streamflow gage be installed downstream of the landslides to replace a now-dysfunctional instrument. This gage would provide an indication of surficial hydrologic response of the region and also give an indication of whether landslide movement has blocked or constricted the river. If desired, this gage could be supplemented by one or more laser distance meters perpendicular to the channel to observe closure of the stream channel.

\section{Kłodne Landslide}

The Kłodne landslide is located east of the city of Limanowa and west of the city of Nowy Sacz, in the Beskid Wyspowy region of the Outer Western Carpathian Mountains. Although the Kłodne area is known to contain landslides, local residents thought that this particular area was inactive. The most recent activity began at approximately 2 a.m. on June 3, 2010, and continued for about 6 hours. The resultant deformation, with up to $12 \mathrm{~m}$ horizontal displacement at the toe, destroyed 16 houses. In addition, several nearby houses on the right flank potentially are in danger if the landslide boundaries grow, and a municipal drinking-water supply well, located just off the left flank of the landslide, could be threatened by additional landslide movement.

The current landslide is approximately $300 \mathrm{~m}$ wide and 1,000 m long. The depth of the basal shear zone over the majority of the landslide is unknown. Overall, the landslide surface has gentle slope, averaging approximately 10 degrees over the length of the landslide. Surficial expression of the landslide is highly visible in a well-defined head scarp, with up to $10 \mathrm{~m}$ of vertical offset; an exposed shale-controlled basal shear zone dipping at 14 degrees along the upper right flank of the landslide; several sag ponds formed within graben; a prominent bulging toe; and many internal scarps, deformed trees, and cracked ground. Some cracks are at least $5 \mathrm{~m}$ in depth. The landslide is located in 
Magura and Sub-Magura rock-series units, present at this locality as a normal flysch deposit. Whereas the exposed shale section of the basal shear zone near the head scarp suggests sliding in this layer, it is unknown if sliding is occurring in this layer throughout the landslide. As of September 2010, some mapping of major landslide morphological features had occurred, but no instrumentation had been installed.

This landslide is a significant hazard, as continued movement or expansion of the landslide boundaries could threaten additional houses and infrastructure. For this reason, we suggest that the structural features of the landslide (Fleming and Johnson, 1989; Fleming and others, 1999) be mapped in detail on the existing base of high-resolution lidar topography and that the site be instrumented with a near-real-time warning system. In addition, several geodetic-grade GPS survey marks should be established as soon as possible to provide a minimum of monthly repeat measurements to determine any remaining landslide movement. At least one target should be established on the lower right flank, where an existing hazard zone has been delineated, to assist with continued monitoring of this area. Geomorphologic mapping should aim to distinguish, as best possible, the internal structure of the landslide by using the vast availability of visible surficial features (for example, scarps, sag ponds, graben, and displacement vectors from trees, electrical posts, and structures) and the existing, post-landslide, airborne lidar data set already available for this region. The goal should be to develop a structural/kinematic model of landslide mechanics and motion to guide design of a detailed instrumentation layout (Baum and Fleming, 1991; Baum and Reid, 1995). Based on the results of landslide kinematic mapping, this site may provide a good location to install a series of ultra-short-baseline $(<1 \mathrm{~km})$ differential-GPS monitoring receivers for near-real-time monitoring. It is likely that several GPS receivers located along the toe in regions of potential landslide growth and displacement would assist in alerting about potentially threatened houses and infrastructure. Flank extensometers might also serve this purpose and would provide a potentially less expensive option. At least two inclinometers in the main body of the landslide would also assist in constraining basal shear-zone location. Given the likelihood that the landslide is responding to water infiltration at depth, the basal shear zone should be screened and monitored with piezometers at each boring location. Finally, given the large scale and complicated structural and kinematic components of this landslide, we think it may provide a good setting for a researchmonitoring program. Research questions could be aimed at delineating how the surface morphology is related to either basal shear-zone topography or internal deformation (for example, Baum and Fleming, 1991), or address the role of subsurface hydrology in rapid versus more creeping components of motion. Depending on the level of instrumentation selected for this site, a research monitoring program could be implemented to take advantage of the proposed monitoring data streams.

\section{Siercza Landslide}

The Siercza landslide is located in the Pogórze Wielickie region of the Outer Western Carpathian Mountains and is situated just outside the city of Wieliczka, an area famous for its historical salt-mining district. Mining of the salt deposits to a depth of more than $300 \mathrm{~m}$ during the past 700 years has led to considerable subsidence in the area, and PGI is currently involved in a project to measure this subsidence using synthetic aperture radar (SAR) interferometry (Perski and others, 2009). Several damaged houses 
have been used as reflectors in previous SAR analyses, and they indicate long term (1992-2000) landslide-related, downslope-sliding deformation on the order of 14-18 $\mathrm{mm} / \mathrm{yr}$. In 1997, four houses were destroyed by precipitation-induced landslide movement. Additional storm-induced landslide movement in May-June of 2010 caused destruction of several more houses and threatened a municipal road. To protect the road, the municipality is constructing a soldier pile wall between the road and the head scarp of the most recent activation. Currently, 18 occupied houses remain within the mapped landslide boundaries, although not all areas of the landslide are equally active.

The currently active landslide is approximately $500 \mathrm{~m}$ wide and $600 \mathrm{~m}$ long with a basal shear zone located 8 to $11 \mathrm{~m}$ below the surface near the head and 16 to $24 \mathrm{~m}$ below the surface in the main body of the landslide. Multiple scarps are evident along the downslope length of the landslide and PGI mapping of the head scarp indicates at least 6 $\mathrm{m}$ of vertical displacement. The landslide is located within highly fractured and sheared, shale-dominated flysch deposits that have weathered to red-brown clays. In 2008, six inclinometer/piezometer nests were installed within the landslide mass, however excessive deformation has already destroyed two of these nests. Maximum deformation in these two holes occurred at shallow depths between 2 and $4 \mathrm{~m}$, indicating less rapid deformation at depth. The remaining inclinometers are measured once per month, whereas piezometer levels are logged once per hour and manually downloaded periodically. According to PGI personnel, piezometric levels have been generally stable, indicating consistent inflow and outflow water volumes to the landslide. During our site visit, which occurred after recent rains, we observed many wet areas on the slope surface resulting from open seeps and springs.

Based on our field visit with PGI personnel and review of site-related documents, we find that the existing monitoring protocols with regard to inclinometers and piezometers are sufficient, but we also suggest some additional instrumentation. Specifically, we suggest that casings at inclinometer I-2 and I-6 be fitted with either multiple-cabled extensometers or time-domain reflectometry (TDR) probes (coaxial cable inside a small diameter, grout-filled PVC pipe and read with a cable tester; see Dowding and others, 1989) before the casings are sheared completely due to ongoing deformation. This new instrumentation would provide a means for continued deformation monitoring (displacement measured using extensometers or depth of shear obtained using TDR) at these locations and potentially at multiple depths depending on the quantity of instrumentation installed. If fitted with deformation-monitoring instrumentation, inclinometer I-2 could also serve as a performance-monitoring device for the soldier pile wall currently under construction at the head scarp of the landslide. Alternatively, the wall itself could be monitored with repeat, high-accuracy GPS measurements or strain gages to measure any wall deformation as part of a performance monitoring plan. Additionally, piezometric levels should be carefully monitored, as the wall could potentially change the subsurface hydrology by routing groundwater either around or below the wall; this may then affect the potential for continued deformation of the main landslide mass downslope from the wall.

Depending on PGI requirements for a hazard warning system, we find that this site could serve as a near-real-time monitoring site for early warning. Near-real-time monitoring might be desirable here in light of (1) landowner reluctance to implement drainage improvements or other engineered mitigation works, (2) potential damage to an 
important road, and (3) the brittle nature of unreinforced masonry houses on the landslide. Although the site does have some mitigation structures, these are unlikely to significantly affect the continued deformation of the landslide below the improvements. Thus, continuous surface (through geodetic GPS) or subsurface (through inclinometers/subsurface extensometers) deformation monitoring could provide an indication of impending landslide-rate increase. Additionally, we suggest that the main basal shear-zone depth be monitored with piezometers isolated in that zone so that pore water pressures can be measured precisely where they are likely to have the most effect on deformation. These monitored pressures could be included in a working, deterministic slope stability model, previously calibrated to determine what level of pore water pressure is required for landslide movement.

\section{Łaśnica Landslide}

The Łaśnica landslide is located between the Pogórze Wielickie and Beskid Makowski regions of the Outer Western Carpathian Mountains near the city of Lanckorona. The current landslide boundary is contained entirely within an older mapped landslide deposit. The current reactivation began on May 19, 2010, and has destroyed or damaged 30 homes. In addition to continued deformations to structures, the landslide also has the potential to block a stream (Potok Cedron) located just below the landslide toe.

The current landslide reactivation is approximately $300 \mathrm{~m}$ wide and $350 \mathrm{~m}$ long with a basal shear zone at about 14-m depth and overall ground surface inclination of 14.6 degrees. Surficial expression of the landslide includes hummocky ground and about three $40-\mathrm{cm}$-tall internal scarps near the head. The landslide is a dip slope $\left(15^{\circ}\right)$ feature within a sandstone-dominated flysch with massive sandstone blocks and very thin shales. Portions of the landslide mass have been mapped as surficial colluvial deposits up to 10 $\mathrm{m}$ in thickness. As a result of the continued threat to homes in the area, the local municipality drilled two borings within the landslide boundaries. The first boring, located at about the landslide mid-slope, quickly sheared at about 14-m depth in response to surface deformations of up to $21 \mathrm{~cm}$ /day before development as an inclinometer could be completed. The second boring, located closer to the head scarp, was successfully developed as an inclinometer and has not yet sheared. It is currently being monitored on a monthly basis. No piezometers were installed during the drilling effort. According to PGI personnel, active seepage and slumps have been observed in the colluvial layer of the landslide mass, but no seepage above the head scarp has been observed.

Depending on PGI requirements for a hazard warning system, we find that this site could serve as a near-real-time warning system site. Monitoring continued deformation and subsurface hydrologic response of the landslide would serve to provide potential warning of increasing deformation rates or the progress of pore pressure generation along the basal shear zone. Before location and selection of instrumentation, we suggest that a thorough investigation of the subsurface deposits, through either existing or new drilling and geomorphologic mapping of the surface expression of the landslide, be performed. This mapping would guide placement of either surface (GPS) or subsurface (downhole extensometer) deformation instrumentation and subsurface hydrology (piezometer) monitoring instrumentation. As at the other sites, we suggest that piezometers be screened over the interval immediately above the basal shear zone (to 
prevent shearing of instrumentation) to provide an indication of pore water pressures that could lead to instability of the landslide.

\section{Łazki Landslide}

The Lazki landslide is located in the Beskid Małego region of the Outer Western Carpathian Mountains north of the city of Żywiec. The landslide is adjacent to Międzybrodzie Reservoir, a flood-control reservoir built prior to 1939. Reactivation of this landslide began in May 2010, with average displacements of $20 \mathrm{~cm} / \mathrm{day}$. According to police authorities, displacements continued to be up to $1 \mathrm{~cm}$ /day during the time of our site visit (mid-September 2010). Seventy homes, mostly summer cottages, are directly affected by continued landslide motion, and many of these homes have been rendered uninhabitable due to excessive wall and (or) foundation deformation. In addition, there is debate about whether or not rapid acceleration of the landslide could occur and lead to a landslide-generated tsunami in Międzybrodzie Reservoir. Waves from such an event could potentially overtop the dam located roughly $1.5 \mathrm{~km}$ downstream from the landslide.

The currently active landslide is approximately $350 \mathrm{~m}$ wide and $500 \mathrm{~m}$ long. The head area slopes as much as 36 degrees, but the overall ground-surface slope from head to shoreline is about 8 degrees. The basal shear-zone depth has been inferred to be at least $30 \mathrm{~m}$ as determined by observations of the reservoir side-slopes at low-water levels, where no basal shear zone could be located. Thus, previous investigators have suggested that the basal shear zone is below this level. At least five major internal scarps have been mapped, each with about 2-3 m horizontal displacement and 1-2 m vertical displacement. Near the current head scarp, an older relict graben feature with about $6 \mathrm{~m}$ vertical displacement is visible. Near the toe, some buildings show clear effects from compressional motion, suggesting a passive zone at this location. Understanding the surficial expression of the landslide is further complicated by observations of landslide sections containing buildings with relatively little or no damage, as well as landslide sections containing buildings with considerable damage. Thus, it is likely that some parts of the landslide are translating downslope without excessive internal deformation. PGI geologists have suggested that this could be an example of a complex block-slide type landslide. The landslide is located in a highly fractured sandstone-dominated flysch (Godula beds of the Silesian rock series unit) and cuts across bedding. Thick colluvial deposits are found throughout the site. Near the head scarp, the colluvium thins considerably to less than $0.5 \mathrm{~m}$ depth. PGI geologists have investigated the overall geological structure of the landslide and hypothesize that the upslope boundary may be formed in a joint-controlled tectonic framework, as evidenced by uncomformably oriented sandstone beds in contact with one another.

Depending on PGI requirements for a hazard warning system, we find that this site could serve as a near-real-time warning system site. In addition, given this site's proximity to a large reservoir and the possibility that sudden deformation could lead to landslide-generated tsunami overtopping of the dam, this site may also be a good candidate for implementation of a real-time warning system. However, probability of rapid catastrophic movement seems low given the gentle overall slope $\left(8^{\circ}\right)$ and the landslide's similarity to other slow-moving landslides in the region. Nevertheless, determination of the hazard posed by landslide-reservoir interactions should first be established through detailed landslide geomorphologic mapping and development of 
appropriate deterministic slope stability analyses. These analyses may help guide whether a real-time warning system is needed at this location. If these analyses can determine whether or not future landslide movements are expected to be rapid (for example, a major drop in peak to residual shear strength, or other rheological-type analysis), the landslide may not pose the hazard necessary to implement such a system. Regardless of the type of monitoring selected, we suggest that the site be first mapped in detail to guide instrumentation selection and placement. The goal of the mapping should be to identify primary active structures and landslide extents at the toe and to make an assessment of landslide kinematics. Whereas the majority of mapping likely can be performed by conventional surface methods, we suggest that large-diameter borehole mapping be considered to identify basal shear-zone depth. Such drilling would need to be done at least $30 \mathrm{~m}$ above reservoir level to avoid flooding of the hole. In addition, some form of bathymetric mapping of the reservoir side slopes may provide a better indication of the location and extent of the landslide toe. We suggest investigating the use of airborne lidar for mapping the terrestrial portion of the site and potentially using a blue/green waterpenetrating laser for the submarine portions of the site. However, any use of airborne laser mapping should carefully investigate the likely ground returns expected from such a survey, as portions of the site are highly vegetated. Given the potential complexity of the landslide itself, we find that ultra-short baseline $(<1 \mathrm{~km})$ differential GPS is the most appropriate type of instrumentation for detecting potential landslide movements. However, this may require many $(6+)$ receivers to adequately monitor all active areas of the landslide. At least two receivers would be needed in the relatively undeformed and apparently most rapid-moving part of the landslide. GPS monitoring could be supplemented by extensometers or laser distance meters at the landslide flanks and head scarp. Piezometers at the basal shear zone would be needed for long-term monitoring and assessment of the stability of the landslide mass. We recognize that for safety reasons, all subsurface exploration might need to be postponed until the landslide's current movement has stopped. If real-time monitoring and associated protocols are selected, any data streams resulting from instrumentation must be adequately analyzed and disseminated, such that all affected parties know the implications of any potential alerts in a timely manner. Such protocols might address the following questions:

- Will shoreline areas be evacuated?

- Will reservoir levels be drawn down, and if so, will this further affect landslide instability through a rapid drawdown scenario?

- Will below-dam inhabitants be evacuated?

\section{Siedloki Landslide}

The Siedloki landslide is located on the side of a steep valley in the hamlet of Siedloki, east of the village of Milówka, in the Beskid Żywiecki region of the Outer Western Carpathian Mountains. The area had been mapped previously as an inactive landslide deposit. Movement was first noticed on September 3, 2010, and by September 14, 2010, horizontal and vertical displacements of about $7.5 \mathrm{~m}$ and $3 \mathrm{~m}$, respectively, had occurred. Movement began following a period of prolonged rainfall (approximately 100 $\mathrm{mm}$ precipitation in two days). At the time of our site visit, seeps and wet ground were visible in many locations on the landslide surface. Four houses were destroyed by 
deformation and several others were damaged. Additionally, the landslide toe destroyed the single road accessing approximately 50 additional homes beyond the landslide limits and completely blocked a stream (Potok Milowski) at the base of the valley. At the time of our reconnaissance (September 14, 2010), a new stream channel had been dredged through the landslide toe, and surveyors were laying out a temporary road through the landslide debris to access the currently isolated homes upstream of the landslide.

The currently active landslide is approximately $280 \mathrm{~m}$ wide and $430 \mathrm{~m}$ long with an unknown depth. Surficial expression of the landslide is evidenced by distinct head and side scarps, as well as internal scarps, cracked ground, and graben. In general, landslide features are suggestive of an undulating basal shear surface at depth, although little is currently known about the basal shear zone. The landslide is developed in sandstones and shales of the Magura rock series unit, present at this locality as a normal flysch deposit. In general, bed thickness is largest at the head scarp and noticeably thinner at the toe. Regional bedding is folded and dips in-slope (opposite to the direction of topographic slope) over the landslide surface as part of a structural anticline. Due to the recent reactivation of this landslide, there is currently no instrumentation installed.

Our general suggestions include performing surficial geomorphologic mapping to define landslide elements and geotechnical drilling to determine basal shear-zone depth. Upon completion of drilling, borings should be developed with inclinometers/piezometers. We suggest, at a minimum, three inclinometer/piezometer nests aligned along the main axis of the landslide to provide a longitudinal section parallel to the movement direction of the landslide. Piezometers should be developed to sample pore-water pressure at the basal shear zone. Given this landslide's influence on nearby residences, we suggest that it be developed as a near-real-time warning system monitoring site. Instrumentation should include downhole tiltmeters and (or) cable extensometers, depending on current rates of landslide motion, and ultra-short baseline $(<1 \mathrm{~km})$ differential-GPS monitoring in areas of potential surface deformation. These should be monitored hourly, or more frequently during periods of rainfall, to provide an indication of impending, large-scale landslide deformation. This site may prove to be a good candidate for repeat terrestrial-lidar-based monitoring. In addition to the surface being free of significant vegetation in many locations (thus making surface morphological features visible), the site also has line-of-site to the hillslope opposite the landslide, which offers a suitable location for a laser instrument. A near-perpendicular line of site typically maximizes lidar point-cloud density over a wide area from a single vantage point. A potential limitation for terrestrial lidar monitoring is most lidar instrument's limited range, as potential laser-instrument locations on the opposite valley slope are about 1,000-1,200 m from the upper areas (farthest areas) of the landslide surface. However, several vendors manufacture lasers with this distance capability, thus an investigation of the potential for implementation of this method is warranted. If movement of this landslide continues, its potential for blocking the stream, Potok Milowski, and creating upstream and downstream flooding hazards may warrant a separate real-time warning system. Streamflow gages upstream and downstream of the toe of the landslide could be monitored at hourly or shorter intervals to detect upstream ponding and downstream reduction in flow (Harp and others, 2008). In addition, laser distance sensors positioned on the south bank of the stream could measure advancement of the landslide toe at the same intervals. It is unlikely that terrestrial lidar monitoring 
Table 1. Summary monitoring suggestions for landslide sites visited in Poland, September 2010.

\begin{tabular}{|c|c|c|c|c|}
\hline $\begin{array}{l}\text { Landslide } \\
\text { name }\end{array}$ & Risk description & $\begin{array}{l}\text { Monitoring } \\
\text { purpose }\end{array}$ & $\begin{array}{l}\text { Current and } \\
\text { suggested } \\
\text { observations }\end{array}$ & General suggestions' \\
\hline Just & $\begin{array}{l}\text { Road subject to } \\
\text { damage. }\end{array}$ & $\begin{array}{l}\text { Near real } \\
\text { time }\end{array}$ & $\begin{array}{l}\text { Displacement, } \\
\text { pore pressure, } \\
\text { precipitation }\end{array}$ & $\begin{array}{l}\text { Possibly add strain measurements } \\
\text { near road, add piezometers, } \\
\text { monitor reservoir level }\end{array}$ \\
\hline Hańczowa & $\begin{array}{l}\text { Road subject to } \\
\text { damage. } \\
\text { Mitigation } \\
\text { measures } \\
\text { installed. }\end{array}$ & Performance & $\begin{array}{l}\text { Displacement, } \\
\text { pore pressure, } \\
\text { precipitation, } \\
\text { strain }\end{array}$ & $\begin{array}{l}\text { Continue current monitoring and } \\
\text { add periodic observations of toe } \\
\text { buttress }\end{array}$ \\
\hline $\begin{array}{l}\text { Szymbark } \\
\text { (Huciska, } \\
\text { Zapadle) }\end{array}$ & $\begin{array}{l}\text { Road and houses } \\
\text { subject to damage. }\end{array}$ & $\begin{array}{l}\text { Near-real- } \\
\text { time }\end{array}$ & $\begin{array}{l}\text { Displacement, } \\
\text { pore pressure, } \\
\text { precipitation, } \\
\text { streamflow }\end{array}$ & $\begin{array}{l}\text { Add GPS or borehole } \\
\text { extensometers, piezometers, and } \\
\text { inclinometer upslope, possibly add } \\
\text { streamflow gage or observe stream } \\
\text { closure using laser }\end{array}$ \\
\hline Kłodne & $\begin{array}{l}\text { Houses subject to } \\
\text { damage. } \\
\text { Municipal water } \\
\text { supply well and } \\
\text { additional homes } \\
\text { threatened. }\end{array}$ & $\begin{array}{l}\text { Near-real- } \\
\text { time, } \\
\text { Research }\end{array}$ & $\begin{array}{l}\text { Displacement, } \\
\text { pore pressure, } \\
\text { precipitation }\end{array}$ & $\begin{array}{l}\text { Structural/kinematic mapping }{ }^{2} \text { and } \\
\text { basal shear-zone depth needed, } \\
\text { potential enlargement needs to be } \\
\text { monitored, good candidate for } \\
\text { GPS, possible flank extensometer }\end{array}$ \\
\hline Siercza & $\begin{array}{l}\text { Roads and houses } \\
\text { subject to damage. }\end{array}$ & $\begin{array}{l}\text { Near-real- } \\
\text { time, } \\
\text { Performance }\end{array}$ & $\begin{array}{l}\text { Displacement, } \\
\text { pore pressure, } \\
\text { precipitation }\end{array}$ & $\begin{array}{l}\text { Continue current monitoring and } \\
\text { add GPS or downhole } \\
\text { extensometer, observe potential for } \\
\text { downslope enlargement }\end{array}$ \\
\hline Łaśnica & $\begin{array}{l}\text { Roads and houses } \\
\text { subject to damage. }\end{array}$ & $\begin{array}{l}\text { Near-real- } \\
\text { time }\end{array}$ & $\begin{array}{l}\text { Displacement, } \\
\text { pore pressure, } \\
\text { precipitation }\end{array}$ & $\begin{array}{l}\text { Structural/kinematic mapping }{ }^{2} \\
\text { needed, add GPS or extensometers } \\
\text { and piezometers }\end{array}$ \\
\hline Łazki & $\begin{array}{l}\text { Houses subject to } \\
\text { damage. Threat of } \\
\text { landslide-induced } \\
\text { tsunami and } \\
\text { nearby dam } \\
\text { overtopping. }\end{array}$ & $\begin{array}{l}\text { Near-real- } \\
\text { time or } \\
\text { Real-time }\end{array}$ & $\begin{array}{l}\text { Displacement, } \\
\text { pore pressure, } \\
\text { precipitation }\end{array}$ & $\begin{array}{l}\text { Structural/kinematic mapping }{ }^{2} \text { and } \\
\text { basal shear-zone depth needed, add } \\
\text { GPS or extensometer at flank, add } \\
\text { inclinometers, and collect near- } \\
\text { shore bathymetry }\end{array}$ \\
\hline Siedloki & $\begin{array}{l}\text { Houses subject to } \\
\text { damage. } \\
\text { Landslide toe } \\
\text { overruns access } \\
\text { road to village and } \\
\text { blocks stream at } \\
\text { toe with flooding } \\
\text { hazard. }\end{array}$ & $\begin{array}{l}\text { Near-real- } \\
\text { time }\end{array}$ & $\begin{array}{l}\text { Displacement, } \\
\text { pore pressure, } \\
\text { precipitation, } \\
\text { streamflow }\end{array}$ & $\begin{array}{l}\text { Structural/kinematic mapping }{ }^{2} \text { and } \\
\text { basal shear-zone depth needed, add } \\
\text { GPS or extensometer at flank, } \\
\text { possible candidate for terrestrial } \\
\text { lidar or total station monitoring of } \\
\text { landslide body or laser monitoring } \\
\text { of toe displacement, possible } \\
\text { candidate for streamflow gage } \\
\text { monitoring }\end{array}$ \\
\hline
\end{tabular}

${ }^{1}$ This list is not comprehensive. Additional suggestions and details are provided in the text of this report.

${ }^{2}$ Structural/kinematic mapping requires high-resolution topography as obtained, for example, by airborne lidar. 
from clearings high on the opposite valley slope would detect toe deformation because of poor toe visibility from that vantage point.

\section{Example of a Near-Real-Time Warning System}

We present the following description of a near-real-time warning system monitoring approach for a hypothetical landslide in the Polish Carpathians. Here, we assume that the purpose of monitoring is to monitor and detect when landslide-prone conditions are occurring in a particular region. The landslide, along with several others, would thus have been selected previously to be representative of typical landslide geometries and topography for the region under investigation. Because deep-seated landslides are typically complicated and potentially unique with respect to specific hydrologic conditions and ensuing motion, any attempt at regional forecasting should rely on the results from several monitored landslides. In this hypothetical example for one landslide, we assume that the landslide geometry, basal shear-zone depth, and general subsurface hydrology are known from previous investigations that included drilling three inclinometers and a single groundwater observation well. We also assume that direct line power and cell phone reception are available at the site.

The hypothetical landslide (fig. 2) is $400 \mathrm{~m}$ wide and $600 \mathrm{~m}$ long and occurs in normal flysch and overlying colluvium. The longitudinal topographic profile of the landslide surface is slightly concave upward with an overall slope of 8 degrees from the head scarp to the toe. Measurements at three inclinometers indicate the basal shear zone is 15-18 $\mathrm{m}$ deep in the main body of the landslide and 13-m deep near the toe. Prior to conversion of the site to a near-real-time monitoring site, one of the inclinometer boreholes sheared, preventing any additional instrumentation in this hole. The toe of the landslide is adjacent to a stream, which erodes the toe during high flows and floods. Water table depth ranges from about 5 to $8 \mathrm{~m}$ annually at an observation well near the center of the landslide, and occasionally, water has been observed seeping from the toe during the latter part of the wet season. Annual displacement ranges from 0 to $0.2 \mathrm{~m}$ during average years and has been as much as $1.5 \mathrm{~m}$ during extremely wet years, such as 1997 and 2010. Careful geomorphologic mapping of landslide structural features, such as scarps, cracks, shear zones, and folds, combined with the analysis of displacement data revealed the extent of zones of longitudinal stretching and shortening. High-resolution topography derived from airborne lidar or digital photogrammetry provides a satisfactory base for such detailed mapping. The upper $120 \mathrm{~m}$ is stretching longitudinally, a neutral (relatively undeformed) zone exists 120-250 $\mathrm{m}$ downslope from the head scarp, and the lower $350 \mathrm{~m}$ of the landslide (250-600 $\mathrm{m}$ downslope from the head scarp) is shortening longitudinally. The neutral zone is usually the most rapidly moving part of the landslide (Baum and Fleming, 1991).

Table 2 summarizes our suggested monitoring plan for the hypothetical landslide. The plan includes a basic monitoring system that could be used at all landslides monitored by PGI, and it lists extra sensors that could be added where needed at particular landslides. Listed quantities represent the minimum number of sensors needed to observe and measure surface deformation, subsurface water, and weather conditions. Three stations for measuring pore pressure at the basal shear zone and displacement within the slide mass, along with a basic weather station constitute the core sensors ("high" priority) for the monitoring system. These stations are located in the upper, 


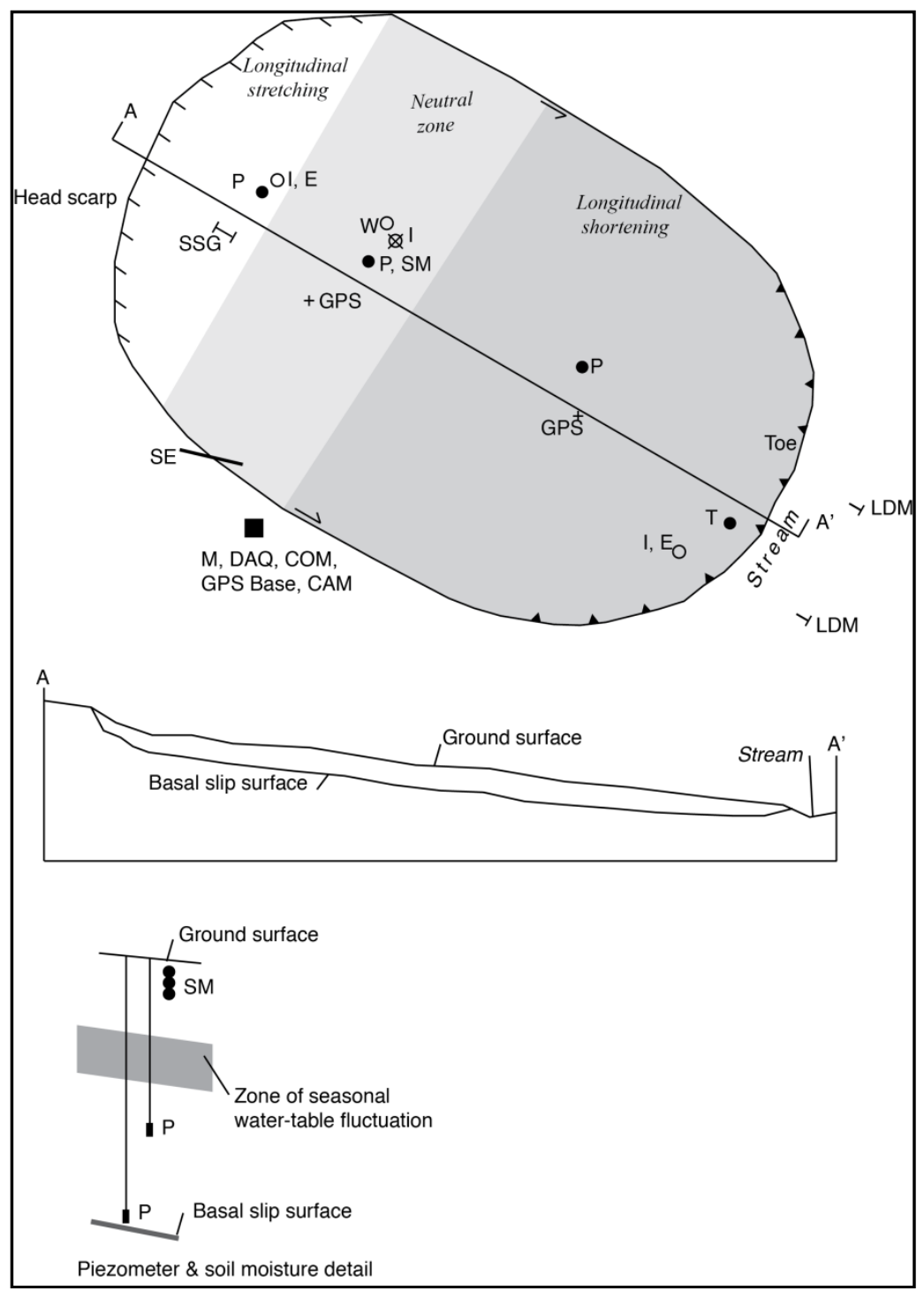

Figure 2. Sketch map, cross section, and details, of hypothetical landslide. W, groundwater observation well; I, borehole inclinometer (" $x$ " through the symbol denotes that the casing has been sheared at the base of the landslide prior to conversion to a near-real-time monitoring site); $\mathrm{P}$, piezometer; $\mathrm{E}$, downhole extensometer; SE, surface extensometer (an alternative to GPS where the landslide has well-developed head scarp or lateral shear zone at flanks); GPS, station for continuous GPS monitoring; GPS Base, GPS base station; LDM, laser distance meter; SM, soil-moisture sensors and (or) tensiometers; SSG, soil-strain gage; T, borehole tiltmeter; $\mathrm{M}$, meteorological sensors (for example, rain gage, thermometer, barometer); DAQ, data-acquisition system or datalogger; COM, communications link; CAM, camera. The GPS base station, data-acquisition equipment, communications link, camera, and meteorological sensors are located well off the landslide on stable ground. The observation well and inclinometer holes (shown as open circles) are assumed to exist from an initial investigation, prior to installation of equipment for near-real-time monitoring. 
middle, and lower sections of the landslide along the main axis, whereas the weather instruments may be located on or off the landslide, as convenient. Two rain gages are suggested for redundancy. The system may be supplemented with additional sensors ("medium and "low" priorities) for observing infiltration of surface water (water content sensors, tensiometers), complex deformation (tiltmeter, soil-strain gage), and toe displacement (laser distance meters), and with a digital camera for recording daily images of the site. Additional piezometers between the basal shear zone and the seasonal low water table would help in defining flow directions and hydraulic gradients within the landslide. Hourly data transmission from all sensors is probably adequate for this type of monitoring, although it could be more frequent during times of landslide movement.

Several options exist for displacement measurement, each with various advantages and disadvantages. For example, upon installation, inclinometer casings can be fitted with a permanent stack of borehole tiltmeters to automate traditional inclinometer measurements. These can be read as frequently as desired and provide a depth profile of displacement in two orthogonal directions, but at considerable cost. Once landslide displacement exceeds several centimeters, the tiltmeter in the basal shear zone will either break or tilt beyond its useful range. Downhole extensometers give an approximate measurement of downslope displacement, are usually quite sensitive to small displacements, and can measure displacements of tens to hundreds of centimeters with adequate construction and maintenance. Extensometers on the surface across the flank or head scarp can have similar performance. Laser distance meters have the advantage of making noncontact measurements, providing relatively rapid response, and are of high accuracy. In addition, some laser distance meters are capable of making measurements directly on the ground surface, rather than using a target. Laser distance meters have somewhat higher power requirements (2-6 W) than other sensors; datalogger control ports can be used to switch to power on and off, and thus conserve power. Beam trajectory is fixed upon installation; consequently, the observed point on a moving landslide may change through time and introduce uncertainty into the displacement measurement.

GPS monitoring is capable of providing three-dimensional displacement measurements with subcentimeter accuracy. Such measurements usually require highcost dual-frequency (L1, L2) receivers and commercial or open-source software may be available to perform the necessary processing and plotting in near real time (see http://www-gpsg.mit.edu/ simon/gtgk/index.htm). Although the technologies exist for real-time GPS monitoring using geodetic-grade equipment, some in-house development would probably be required to make the technologies work together to meet PGI's needs. High-accuracy displacement measurements in near real time have also been achieved using inexpensive single frequency (L1) receivers, ultra-short $(<1 \mathrm{~km})$ baselines, and custom software (Reid and others, 2008; Harp and others, 2008). Unfortunately, we know of no complete, currently available, commercial or open-source solutions for this application. PGI could probably develop this capability in-house through collaboration of its GPS and IT specialists. In all cases of hydrologic and displacement instrumentation, additional redundant sensors may be desired in cases where monitored data streams tie directly into a warning system. As such, paired piezometers or extensometers, for example, should be considered, but are not detailed as a part of this hypothetical example. 
Table 2. Equipment for near-real-time monitoring of hypothetical landslide.

\begin{tabular}{|c|c|c|c|c|}
\hline Location & $\begin{array}{c}\text { Depth } \\
\text { (m) }\end{array}$ & Sensor or equipment type ${ }^{1}$ & Quantity & Priority \\
\hline Zone of & 10 & Piezometer $^{2}$ & 1 & Medium \\
\hline longitudinal & 15 & Piezometer $^{2}$ & 1 & High \\
\hline stretching & 0 & Down-hole extensometer ${ }^{3}$ & 1 & High \\
\hline$(0-120 \mathrm{~m})$ & 1.5 & Soil strain gage/soil extensometer ${ }^{4}$ & 1 & Medium \\
\hline \multirow{4}{*}{$\begin{array}{l}\text { Neutral zone } \\
(120-250 \mathrm{~m})\end{array}$} & 10 & Piezometer $^{2}$ & 1 & Medium \\
\hline & 18 & Piezometer $^{2}$ & 1 & High \\
\hline & 0 & GPS receiver ${ }^{5}$ or surface extensometer ${ }^{3}$ & 1 & High \\
\hline & $0.5,1,2$ & Water content sensor and (or) tensiometers ${ }^{6}$ & 3 & Medium \\
\hline Zone of & 8 & Piezometer $^{2}$ & 1 & Medium \\
\hline longitudinal & 13 & Piezometer $^{2}$ & 1 & High \\
\hline shortening & 0 & Down-hole extensometer ${ }^{3}$ & 1 & High \\
\hline$(250-600 \mathrm{~m})$ & 0 & GPS receiver $^{5}$ & 1 & High \\
\hline \multirow[b]{2}{*}{ Toe } & 0 & Laser distance meter ${ }^{7}$ & 2 & Medium \\
\hline & 5 & Borehole tiltmeter $^{8}$ & 1 & Medium \\
\hline \multirow{9}{*}{$\begin{array}{l}\text { Flank or Crown } \\
\text { (Off slide) }\end{array}$} & 0 & Tipping bucket precipitation gage $^{9}$ & 2 & High \\
\hline & 0 & Barometer ${ }^{10}$ & 1 & High \\
\hline & 0 & Air temperature sensor ${ }^{11}$ & 1 & High \\
\hline & 0 & GPS base station ${ }^{5}$ & 1 & High \\
\hline & 0 & $\begin{array}{l}\text { Datalogger }{ }^{12} \text {, enclosure, grounding rod, 7-Amp- } \\
\text { hour (or larger) battery and charger }\end{array}$ & 1 & High \\
\hline & 0 & Multiplexer ${ }^{13}$ & 1 & High \\
\hline & 0 & Vibrating wire interface $^{14}$ & 1 & High \\
\hline & 0 & IP modem and antenna ${ }^{15}$ & 1 & High \\
\hline & 0 & Still camera ${ }^{16}$ or webcam & 1 & Low \\
\hline Office & -- & $\begin{array}{l}\text { Windows or LINUX PC or server, Internet } \\
\text { connection, Datalogger communication and } \\
\text { control software }\end{array}$ & 1 & High \\
\hline
\end{tabular}

${ }^{1}$ Any use of trade, product, or firm names is for descriptive purposes only and does not imply endorsement by the U.S. Government.

${ }^{2}$ Casagrande type, with 0.5 -m-long porous tip, and pressure sensor, similar to Geokon 4500 series vibrating wire sensor (http://www.geokon.com/), Slope Indicator, Inc. model 52611020 vibrating wire piezometer (http://www.slopeindicator.com/). See Appendix A, instrument installation.

${ }^{3}$ A 6-mm braided-steel cable is anchored at the bottom of the inclinometer casing. A spring provides tension to counteract the weight of the downhole cable. The free end of the braided cable is attached to a cable-extension transducer (similar to Celesco Transducers, model PT8101, http://www.celesco.com/ or those by UniMeasure, $h t t p: / / w w w . u n i m e a s u r e . c o m /)$. The same instrument, with a lighter cable can be used as a surface extensometer for landslides with well-developed flank or head scarp at lower cost than dual frequency GPS.

${ }^{4}$ Similar to Geokon Soil Extensometer Model 4435.

${ }^{5}$ Similar to equipment offered by Ashtech (http://www.ashtech.com/) or Trimble (http://www.trimble.com/) for subcentimeter accuracy surveys, with software similar to GAMIT (http://wwwgpsg.mit.edu/ simon/gtgk/index.htm) or Waypoint (http://www.novatel.com/products/waypoint-software/).

${ }^{6}$ Similar to Decagon Devices, Inc., Model EC-5 Soil moisture sensor (http://www.decagon.com/) and UMS tensiometer model T8 (http://www.ums-muc.de/en/service_navigation/home.html).

${ }^{7}$ Similar to Sick AG, DT50 or DMT10 series laser distance sensors, depending on the distance between the target on the landslide toe and a stable location for mounting the sensor (http://www.sick.com/).

${ }^{8}$ Similar to Applied Geomechanics Model 906 Little Dipper In-Place Inclinometer (http://www.carboceramics.com/agi/900-series/). 


\footnotetext{
${ }^{9}$ Similar to Met One Instruments, Inc. 300 series precipitation gages (http://www.metone.com/) Two rain gages are suggested for redundancy.

${ }^{10}$ Similar to Met One Instruments, Inc. Model 092 Barometric pressure sensor; otherwise, it is acceptable to use the same model sensor for above ground installation as is used in the piezometers below ground, as long as they are used only for pressure compensation of the sealed sensors (see note 2 above).

${ }^{11}$ Similar to Campbell Scientific, Inc., 107-L Temperature Sensor (http://www.campbellsci.com/).

${ }^{12}$ Similar to Campbell Scientific, Inc., CR1000 measurement and control system. Battery rating for solarpowered systems depends on local climate and sun exposure.

${ }^{13}$ Similar to Campbell Scientific, Inc., AM16/32B Multiplexer.

${ }^{14}$ Similar to Campbell Scientific, Inc., AVW200 vibrating wire interface, used with vibrating wire piezometers.

${ }^{15}$ Similar to Sierra Wireless ${ }^{\mathrm{TM}}$ AirLink Raven XT modem, with YAGI or omnidirectional antenna (http://www.getwirelessllc.com/Airlink.cfm).

${ }^{16}$ Similar to time lapse package offered by Harbortronics (https://www.harbortronics.com/) unlike a webcam, these images would be stored onsite.

${ }^{17}$ Similar to Campbell Scientific, Inc., LoggerNet software, for large networks of remote monitoring stations, software similar to LoggerNet Admin is needed. OPC software could also be used. Telephone modem, radio or satellite base station, or other communications peripheral devices may be needed if remote sites are using cellular modems, radio, or satellite communications.
}

For this hypothetical example, the datalogger and peripherals are housed in a weather-tight enclosure on stable ground near the edge of the landslide where AC electrical power is available. A wireless IP modem would provide rapid communication (similar to text messaging) between the monitoring station and PGI's computer network. At remote sites where cellular coverage and AC power are not available, solar power and radio or satellite communication would be needed. All sensors are connected to and communicate with the datalogger by means of signal cables. Wireless communication between the sensors and dataloggers is also possible where needed; however, it adds to the cost and complexity of the system. One or more multiplexers may be needed to conserve channels on the datalogger by allowing the datalogger to use only one or two channels to read several sensors of the same type. For example, using the vibrating-wire interface in series with a multiplexer could allow six piezometers and the soil-strain gage to be read using only two datalogger channels, one for signal and one for temperature. Appendix A provides additional suggestions for installation of remote automated landslide-monitoring stations.

Field data collection and monitoring, whether manual or automated, are labor intensive and therefore costly activities. A common pitfall in many landslide investigations is underestimating the true costs of instrumental monitoring programs. Estimating the cost of the initial investment in equipment and installation is relatively straightforward. An estimate can be obtained by compiling unit prices for the selected instrumentation from table 2, and computing the total based directly on the selected site instrumentation layout. However, in addition to the initial, one-time costs of background fieldwork and research, and equipment acquisition and installation, the costs of data collection, surveillance (monitoring system performance and data flow), repairs, maintenance, and data processing continue for the life of the project. This may include replacement of instrumentation due to exhaustion of its service life from weathering and continuous use. Although the service life of instruments varies considerably, five years 
seems like a reasonable average based on our experience. Thus, depending on the duration of the project, the continuing costs can approach or, in some cases, exceed the initial investment (Baum and others, 2008).

In an actual near-real-time monitoring system, data from this landslide would be periodically automatically transmitted, graphed, and then analyzed by PGI personnel to deduce if landslide movement was occurring or was imminent. However, the data might also be used in conjunction with data from other nearby monitored landslides to determine if landslide-prone hydrologic conditions exist, in general, for a given region. If any of these conditions were determined to be occurring, it would be the duty of the personnel analyzing the data to take appropriate steps to (1) verify the prognosis of the data analysis and (2) communicate with appropriate internal (PGI staff) and external (public officials) personnel about the meaning of the prognosis in terms of public response. These actions should follow a carefully, predetermined decision matrix with regard to issuing notifications and (or) warnings.

\section{Managing Public Perceptions about Real-Time Landslide Monitoring and Early Warning}

Although this report is primarily about the technical aspects of real-time and nearreal-time landslide monitoring, sociological issues and challenges also influence the effectiveness of warning systems. A complete warning system includes protocols for disseminating warnings and actions to take depending on the level of warning. Development of a real-time monitoring and early-warning system for landslides in the Polish Carpathians will put PGI and landslide monitoring increasingly in the public eye. A wide variety of questions may arise from the public, such as:

- What are landslides and how do I know if my house is on one?

- What should I do if PGI has issued a landslide warning?

- How will landslide monitoring reduce losses or help the public? Is the benefit worth the expense? Is it an appropriate expenditure of public funds?

- If PGI is monitoring all those other landslides, shouldn't they also be monitoring the one that affects my property?

- If PGI is monitoring the landslide on which my village is built, will it (the monitoring) keep us safer? Will the government compensate us for losses?

Such questions arise out of the public's unfamiliarity with relatively infrequent phenomena, such as landslides, and some people may assume that if the government is doing anything about a problem that it is assuming full responsibility. Additional problems associated with false alarms on the one hand, or failure to warn on the other, might result from inherent uncertainties in monitoring data or equipment malfunction. Depending on existing laws, such errors may bear financial liability (especially failure to warn if fatalities or serious injuries occur). Awareness and careful consideration of these and related issues may influence planning of PGI's monitoring program. Dialogue with local and regional authorities, as well as with the emergency-management community and possibly the Polish national weather bureau, will be needed to determine how 
warnings will be handled, what should happen when a warning is issued, and who will be responsible. Once PGI is prepared to address questions about purpose, scope, cost, procedures, roles, responsibilities, liability, and so on, a well-managed public-information campaign will help manage public expectations about landslide monitoring. Sound legal advice may be beneficial as well. For additional information on the complexities of warning systems, see Wilson (2004) and Baum and Godt (2010).

Finally, it is important to note that monitoring up to 100 landslides, as PGI is proposing to do, should be viewed as an ambitious task. Considerable resources, including continuous labor, will be needed to maintain and operate such a system. There are few, if any, existing systems of this scope currently operating in the world (for example, the USGS currently monitors about 10 to 15 sites nationwide), and thus, PGI should be prepared to put forth considerable investment and confront significant challenges in pursuing this goal.

\section{Potential Research Questions To Be Answered By Monitoring}

If PGI embarks on a program of real-time landslide monitoring and (or) near-realtime landslide monitoring for early warning, a research and development effort will be needed. This effort should initially be aimed at developing monitoring procedures and determining research questions suited to landslides in the Carpathians, followed by a period of time in which the accuracy and timeliness of warnings can be gradually improved. The following list of questions is incomplete and touches on only a few of the more obvious topics that could merit further research. Some of these questions address landslide activation, whereas others address monitoring techniques and warning methods. At least some of the research will require laboratory or other techniques in addition to field monitoring. Real-time monitoring allows the collection of synchronous data on landslide movement, hydrological conditions, and related processes. Data synchronicity is necessary for resolving cause-and-effect relationships, and clearly understanding processes that can contribute to predicting landslide behavior.

- How does water move from the surface to the basal shear zones? How does water movement affect timing of landslide movement in relation to rainfall and snow melt?

- Can landslide surface geomorphic expression be linked to geometry of the basal shear zone or must internal deformation (dilation or contraction) be taken into account in deterministic landslide models?

- Can rapid versus creeping areas of landslide motion be linked to differential subsurface hydrologic response?

- Can linkages be established between pore pressure response at the basal shear zone and landslide movement?

- How similar are basal shear zone geotechnical properties of landslides throughout the Carpathians?

- Do regional patterns of hydrological conditions (pore pressures, stream discharge, antecedent precipitation, and so on) exist that can be used as a basis for alerting the general public of increased potential for landslide reactivation? 
- What is the role of reservoir operations, if any, on landslide pore pressure and movement in these particular settings?

- Are ground strains detectable in landslide deposits before ground cracking becomes apparent or displacement becomes measurable?

- How well do inhabitants of the Carpathian region respond to landslide alerts?

\section{Conclusions}

Landslide monitoring is a complicated process, both technically and sociologically. On the one hand, landslides are, by their nature, very complex and require sophisticated research tools and analysis techniques to achieve a detailed understanding of expected motion and acceleration. On the other hand, the implications of detecting motion or impending activation have important ramifications for affected landowners, as well as for officials charged with maintaining public safety and protecting societal loss. Any effort to establish landslide warning systems must rely heavily on the skills and technology available from scientific and engineering research, as well as on creating a solid framework conducive to transferring relevant information to those who need it most.

In this report, we have outlined substantial background information on state-ofthe-art landslide-monitoring techniques to assist PGI with on-going concerns about recent landslide reactivations in southern Poland. This information, coupled with site-specific suggestions for eight landslides visited by USGS personnel in September 2010, provides a framework for developing local monitoring protocols for deep-seated landslides. Developing regional strategies, based on monitoring several representative landslides, will require additional research with regard to how these particular landslides may be used as proxies for regional expectations. In our suggestions, we have highlighted the importance of selecting an appropriate monitoring strategy, consistent with expectations for the use of the data to be collected. Once a strategy is chosen for each site, suggestions for instrument selection and location can be implemented. Sensor deployment should be further refined based on additional site-specific geologic and geomorphologic mapping. Using the monitoring strategies outlined in this report, PGI should be well-positioned to assess landslide activity and assist with making appropriate decisions concerning landslides in the Polish Carpathians.

\section{Acknowledgments}

This report was prepared in collaboration with the Polish Geological Institute, Warsaw, Poland. Ingrid Verstraeten (USGS, International Programs), and Wojciech Brochwicz-Lewinski and Ilona Smietanska (PGI-NGI, International Cooperation Section) conceived and developed this cooperative project between Poland and the United States. Mark Reid, Jeffrey Coe, and Ed Harp of the USGS provided detailed comments that improved the content of this report. 


\section{References Cited}

Alexandrowicz, S., and Alexandrowicz, Z., 1999, Recurrent Holocene landslides: A case study of the Krynica landslide in the Polish Carpathians: The Holocene, v. 9, no. 1, p. 91-99.

Bajgier-Kowalska, M., 2008, Lichenometric dating of landslide episodes in the Western part of the Polish Flysch Carpathians: Catena, v. 72, p. 224-234.

Baum, R.L., and Fleming, R.W., 1991, Use of longitudinal strain in identifying driving and resisting elements of landslides: Geological Society of America Bulletin, v. 103, p. 1,121-1,132 and supplemental data.

Baum, R.L., Galloway, D.L., and Harp, E.L., 2008, Landslide and land subsidence hazards to pipelines: U.S. Geological Survey Open-File Report 2008-1164, 192 p.

Baum, R.L., and Godt, J.W., 2010, Early warning of rainfall-induced shallow landslides and debris flows in the USA: Landslides, v. 7, no. 3, p. 259-272. doi:10.1007/s10346-009-0177-0

Baum, R.L., and Reid, M.E., 1995, Geology, hydrology, and mechanics of a slowmoving, clay-rich landslide, Honolulu, Hawaii, in Haneberg, W.C., and Anderson, S.A., eds., Clay and shale slope instability: GSA Reviews in Engineering Geology, v. X, p. 79-105.

Bednarczyk, Z., 2008, Landslide geotechnical monitoring for mitigation measures in chosen location inside the SOPO Landslide Counteraction Framework Project, the Carpathian Mountains, Poland: Proceedings of the International Consortium on Landslides, First World Landslide Forum, Session 13, p. 468-472.

Chleborad, A.F., Baum, R.L., Godt, J.W., and Powers, P.S., 2008, A prototype system for forecasting landslides in the Seattle, Washington, area, in Baum, R.L., Godt, J.W., and Highland, L.M., eds., Landslides and engineering geology of the Seattle, Washington, area: GSA Reviews in Engineering Geology, v. XX, p. 103-120.

Dowding, C.H., Su, M.B., and O’Connor, K., 1989, Measurement of rock mass deformation with grouted coaxial cables: Rock Mechanics and Engineering, v. 22, p. 1-22.

Fleming, R.W., and Johnson, A.M., 1989, Structures associated with strike-slip faults that bound landslide elements: Engineering Geology, v. 27, p. 39-114.

Fleming, R.W., Baum, R.L., and Giardino, Marco, 1999, Map and description of the active part of the Slumgullion landslide, Hinsdale County, Colorado: U.S. Geological Survey Geologic Investigations Map, I-2672, 3 sheets + pamphlet, $1: 1000$.

Gil, E., and Długosz, M., 2006, Threshold values of rainfalls triggering selected deepseated landslides in the Polish Flysch Carpathians: Studia Geomorphologica Carpatho-Balcanica, Landform evolution in mountain areas, v. XL, p. 21-43.

Gil, E., Zabuski, L., and Mrozek, T., 2009, Hydrometeorological conditions and their relation to landslide processes in the Polish Flysch Carpathians (an example of Szymbark area), Studia Geomorphologica Carpatho-Balcanica, Landform evolution in mountain areas, v. XLIII, p. 127-143.

Harp, E.L., Reid, M.E., Godt, J.W., DeGraff, J.V., and Gallegos, A.J., 2008, Ferguson rock slide buries California State Highway near Yosemite National Park: Landslides, v. 5, no. 3, p. 331-338. 
Institute of Meteorology and Water Management, 2010, http://www.imgw.pl/, last accessed February 17, 2011.

Perski, Z., Hanssen, R., Wojcik, A., and Wojciechowski, T., 2009, InSAR analyses of terrain deformation near the Wieliczka Salt Mine, Poland, Engineering Geology: v. 106, no. 1-2, p. 58-67.

Reid, M.E., Baum, R.L., LaHusen, R.G., and Ellis, W.L., 2008, Capturing landslide dynamics and hydrologic triggers using near-real-time monitoring, in Chen, Z., Zhang, J., Li, Z., Wu, F., and Ho, K., eds., Landslides and engineered slopes from the past to the future: Proceedings of the Tenth International Symposium on Landslides and Engineered Slopes, 30 June-4 July 2008, Xi'an, China, v. 1, p. 179-191: London, Taylor and Francis.

Telegraph, 2010, "Five killed and thousands evacuated as floods hit central Europe," Telegraph.co.uk, Matthew Day, May 17, 2010, http://www.telegraph.co.uk/news/worldnews/europe/hungary/7734010/Fivekilled-and-thousands-evacuated-as-floods-hit-central-Europe.html, last accessed February 17, 2011.

Wilson, R.C., 2004, The rise and fall of a debris-flow warning system for the San Francisco Bay Region, California, in Glade T., Anderson, M., and Crozier, M.J., eds., Landslide hazard and risk: New York, Wiley, p. 493-516.

Wójcik, A., Mrozek, T., and Granoszewsi, W., 2006, Lithological conditioning of landslides and climatic changes with examples from the Beskidy Mts., Western Carpathians, Poland: Geografia Fisica e Dinamica Quaternaria, v. 29, no. 2, p. 197-209.

World Meteorological Organization, 2010, "Flooding in Poland-May/June 2010," http://www.wmo.int/pages/mediacentre/news_members/poland_2010_en.html \#backnews, last accessed February 17, 2011.

Zabuski, L., Wójcik, A., Gil, E., Mrozek, T., and Rączkowski, W., 2009, Landslide processes in a flysch massif - Case study of the Kawiory landslide, Beskid Niski Mts. (Carpathians, Poland): Geological Quarterly, v. 53, no.3, p. 317-332. 


\section{Appendix A. General Considerations for Real-Time and Near-Real-Time Monitoring}

\section{Power}

- Available line power with battery backup is generally more dependable than solar power with batteries.

- A regular maintenance schedule for battery replacement is needed.

- Recording and transmitting raw voltages from sensors reduces overhead on dataloggers. Conversion to engineering units can be done automatically at the office; this also makes it easier to correct conversion errors or apply improved calibration factors or formulas to data collected previously.

\section{Communications}

- When available, wireless IP modem connections are desirable for data transmission; however, uplink of data can include a number of options such as cell phone, satellite, spread-spectrum or dedicated radio link, and land-line telephone.

\section{Instrumentation Layout}

- Landslide instrumentation is often best installed in stages. The first stage of subsurface instrumentation seeks to determine location of the basal shear zone and depth of groundwater. The second stage seeks to refine pore pressure measurements at the basal shear zone and fill in gaps identified during the first stage (Baum and Reid, 1995).

- Ideally, piezometers should be screened over the depth interval just above the basal shear zone. This provides important data that may be used in deterministic assessment of slope stability.

- Equipment redundancy, in the form of multiple installed instruments, greatly improves reliability for real-time operational monitoring.

- Some form of independent measurement (for example, calibrated tape measure or water-level sensor) is useful for periodic recalibration of extensometers, piezometers, and many other types of sensors. 


\section{Instrument Installation}

- Buried cables should be protected from burrowing animals, preferably in a flexible metallic conduit. The conduit need not be waterproof so long as cable insulation is intact and all splices are waterproof. Cables exposed above ground also need to be in flexible metal conduit to prevent animals from chewing the insulation.

- Extensometer cables need to be protected from animal disturbance by placing them either high above the ground or in an enclosure.

- Some types of electronic piezometers are made for direct burial, with the advantage of faster response time and more accurate pressure measurement than Casagrande piezometers. However, for long-term installations, sensor repair or replacement is much easier and less costly when using Casagrande piezometers monitored with a removable electronic piezometer or water-level sensor.

- In all cases, sufficient strain relief should be included for cables, such that upon landslide displacement, cables are not detached from either the instrument or datalogger. This can usually consist of extra, free-coiled cable buried or stored near the instruments and dataloggers. 